\title{
THE POLITICS OF CONSTITUTIONAL DESIGN IN DIVIDED SOCIETIES: THE CASE OF KOSOVO
}

\begin{abstract}
Fisnik Korenica* and Dren Doli**
Summary: This article discusses the politics of constitutional design in Kosovo as a means of softening societal cleavages. The article maps out the problem of societal cleavages in Kosovo, and explains their origins and implications for the state-building process. The article goes on to survey the constitutional law of Kosovo, and discusses its substance in light of the accommodationist-integrationist debate. While attempting to explain the choices that have been made in Kosovo's constitutional law as regards the issue of ethnic cleavages, the article shows the international community's crucial role in Kosovo's state-building process. Having explained the main pillars of Kosovo's constitutional law and its design, the article then argues that the international state-building process in Kosovo has been aimed at reaching harmony between the accommodationist and integrationist approaches to the politics of constitutional design. The article concludes that the international state-building process in Kosovo has been aimed at achieving a balance between the accommodation of ethnic minorities in the Kosovo polity and the efficacy and political stability of the newly formed polity/state.
\end{abstract}

\section{Introduction}

Divided societies have a big challenge to address, namely how to organise an institutional mechanism that will smooth the rapport between societal cleavages. Many countries in the world face divided society problems, whether ethnic, religious, cultural, linguistic or other cleavages, such as Northern Ireland, Bosnia and Herzegovina, Cyprus, the Netherlands, India, Belgium, etc. All these countries, and others that have not been mentioned, face the phenomenon of societal division, each of them

Fisnik Korenica is a lecturer on the Theory of State and Law at the University of Prishtina, and a Senior Research Fellow at the Group for Legal and Political Studies. This paper is written as part of the Assessing Democracy in the Western Balkans research project of the Group for Legal and Political Studies. The authors thank the Research Committee of the Group for Legal and Political Studies for providing in-depth comments and recommendations on the first draft.

** Dren Doli is a Senior Research Fellow at the Group for Legal and Political Studies, and a Senior Lecturer on Principles of Law at Universum University College, having served earlier as a Senior Legal Executive for Integration to the Prime Minister's Office of Kosovo. 
having a cleavage based on ethnicity, religion, culture, language, etc. Kosovo is such an example. The main cleavage that makes Kosovo a divided society is an ethnic one. Kosovan society illustrates a case where people are divided on the basis of ethnicity. Society is practically divided between Albanians on the one hand and Serbs and other minorities on the other, with the Albanians constituting $90 \%$ of the population.

The regulation of relationships between different groups in a divided society such as that of Kosovo is a major issue. In countries with a democratic transition background, this question reveals an even more fundamental issue, namely the existence of the polity itself. The inability to formulate an accommodation policy for societal cleavages, such as for ethnic minorities, might lead to state failure or more broadly to undemocratic governance. In practice, the device that can regulate societal cleavages in a divided society is constitutional law and constitutional design. Driving the process of constitutional accommodation of societal cleavages forward can lead to a more consensual polity with less likelihood of failure. In this context, the politics of constitutional design remain at the heart of the politics of accommodation in divided societies such as Kosovo. Although one cannot expect constitutional law to settle everything in this regard, it at least provides the principles instituting a societal mechanism that softens the rapport between groups. However, the politics of constitutional design in the case of Kosovo are essentially linked with the historical events that shaped the societal cleavages there.

This article seeks to discuss societal division in Kosovo and to analyse the politics of constitutional design as a vehicle for accommodating the cleavages concerned. When considering the case of Kosovo, it is worth noting that, with regard to societal division, models of constitutional design range from pure accommodationist approaches to pure integrationist ones. Therefore, besides discussing the problem from a theoretically informed standpoint, the article endeavours to delineate the border between accommodationist and integrationist approaches from the perspective of Kosovo's constitutional law. By doing so, the article will illustrate the main differences between Kosovo's constitutional design and other models in the world. To begin with, the paper will address the issue of societal cleavage in Kosovo, and will explain what it means from a Kosovan perspective. The paper will then embark on an analyses of Kosovo's constitutional law, and will examine the extent of accommodation that it provides for ethnic minorities. During this analysis, the article will seek to answer whether the model of accommodation provided by the Kosovan constitutional design excludes the possibility of an integrationist approach in the main components of the polity, and if so, how. The article will conclude by offering a view on the debate between accommodationism and integrationism in the case of the politics of Kosovo's constitutional design. 


\section{Kosovan societal cleavages: origins and implications}

Kosovo is a territory that was part of Albanian geographical space in the Western Balkans. However, after the independence of Albania in 1912, Kosovo remained outside its territorial realm. As a result, during and after World War II, Kosovo remained a political entity dominated by Yugoslavia and came under its military administration in the aftermath of WWII. Although ethnic conflict in Kosovo is an old problem in the opinion of many, ${ }^{1}$ it can be argued that it more specifically stems from events that occurred after the death of the longest-ruling Yugoslavian leader, Josip Broz Tito. ${ }^{2}$

After Kosovo became part of a sovereign Yugoslavia, several factors pushed Serbian nationalism to discriminate against the non-Slavic people of Kosovo. However, during the initial period of communist rule in the aftermath of WWII, Kosovo Albanians were barely affected by discrimination against them by the Serbian nationalist elites that dominated the early communist Yugoslavia. However, with the impact of Tito and his more liberal approach towards the nations and nationalities of the federation in which he attempted to regulate relations between the Yugoslavian nations through a more pluralistic approach, Kosovo became a more autonomous and vibrant political entity within Yugoslavia. The growing efforts of Tito to increase both the political position and standard of life of Kosovo within Yugoslavia culminated in a constitutional change in 1974 that reshaped the then-communist Socialist Federal Republic of Yugoslavia. Although levels of ethnic tension before 1974 were rather high in Kosovo, since the Serbian population was targeted as supporters of nationalist Serbian rule in Belgrade, the 1974 constitutional change provided a new momentum in softening ethnic relations and greatly empowered the Albanian people and Kosovo within the federal Yugoslavia. The post-1974 position of Kosovo, because of Tito's policy of reshaping Yugoslavia through a more pluralistic approach, improved greatly, and resulted in an absolute decrease in ethnic tensions in Kosovo. With the 1974 Yugoslavian constitutional system, Kosovo became a constituent part of the Yugoslavian federation, having a veto right on every federal issue. Nevertheless, its territorial name remained somehow linked with Serbia, which signified that Kosovo was not an equal of the other federal units of Yugoslavia. Since support for the federal government for Kosovo was evident and Kosovo made use of its position as a constituent part of the federation to accommodate itself as an almost equal federal unit,

\footnotetext{
1 Independent International Commission on Kosovo, The Kosovo Report: Conflict, International Responses, Lessons Learned (OUP, New York 2000).

2 See N Malcolm, Kosovo, a Short History (Papermac, London 1998); T Judah, Kosovo: What Everyone Needs to Know (OUP, Oxford 2008); Independent International Commission on Kosovo, Kosovo Report: the Origins of the Kosovo Crisis (OUP, Oxford 2000).
} 
ethnic tensions in the aftermath of the 1974 Yugoslavian constitutional changes remained almost frozen or were removed. ${ }^{3}$

With the death of Tito, the Serbian nationalist leadership started to extend its authority over the Yugoslav federation during the 1980s. By assuming more power at the federal level, and by strengthening their position over weaker federal units such as Kosovo, Serbian nationalist leaders stirred up the question of ethnicity and fuelled tension over it. During the same period, the Serbian leadership practically destroyed the pluralist model of Yugoslavian politics that Tito had built, making sure the other Yugoslavian nations understood that dissolution would result in an armed conflict between Serbia and secessionists. With regard to Kosovo, nationalism continued to grow, and the idea was promoted that Kosovo had nothing that could qualify it as having the right to demand an equal position with the other federal republics. This overturned the rationale on which Tito had built an ethnically tension-free Yugoslavia, and encouraged ethnic conflict as a means of achieving certain political targets. ${ }^{4}$

The move towards secession from the federal Yugoslavia grew very fast among Slovenians, Croats, Kosovo Albanians and Bosnians. Following the successful secession of Slovenia, and the gaining of independence from Yugoslavia by Croatia and Bosnia, Kosovo Albanians felt that the only solution was independence. As a result of swift military intervention, Serbia re-established its position as the leading nation within Yugoslavia, and took control of the federal Yugoslavian army. By assuming almost absolute control over the Yugoslavian army, the Serbian political elite took action to militarily save the Federation. In the aftermath of 1990, Serbia made use of its military control over Yugoslavia and rescinded Kosovo's autonomy within federal Yugoslavia. By overturning the 1974 constitutional order, the Milošević clique within Serbia enforced a legal and political regime contrary to the constitutional autonomy of Kosovo within a federal Yugoslavia, while allowing the federal Yugoslavian army to assault those who favoured secession. In response, the Kosovo Albanian political leadership initially declared independence from Serbia and

\footnotetext{
3 Malcolm (n 2); Judah (n 2); E Hasani, The Dissolution of Yugoslavia and the Case of Kosova: Political and Legal Aspects (Albanian Institute of International Studies, Tirana 2000); E Stavileci, Kosova dhe qeshtja shqiptare ne udhekryqet e kohes (A Political History of the Kosovo Issue) (Instituti per Studime Bashkohore, Prishtine 2005); JA Mertus, Kosovo: How Myths and Truths Started a War (University of California Press, LA 1999). See also the integral text of the 1974 SFRY Constitution. The Constitution of the Socialist Federal Republic of Yugoslavia (Ustav Socijalističke Federativne Republike Jugoslavije (Dopisna Delavska , Belgrade 1974)).

4 See, for instance: Hasani (n 3); Independent International Commission on Kosovo (n 2); Stavileci (n 3); E Stavileci, Truths on Kosova (Albanian World Federation, Prishtina 2000); Mertus (n 3).
} 
subsequently from Yugoslavia, a policy which almost failed. However, with the rise of a nationalist policy towards Kosovo in Belgrade, and the assault on the constitutional autonomy of Kosovo, together with the removal of the veto that Kosovo held over federal constitutional changes, Serbia proved that the ethnic component of Kosovo would be the basis for new tensions. ${ }^{5}$

With the rise of the new nationalist regime in Serbia, Kosovo Albanians rigidly opposed the idea of being non-autonomous within a Serbian Yugoslavia. In retaliation, the Kosovo Albanian political leadership organised a parallel political life, and forcibly rejected participation in public life under a Serbian-led Kosovan public administration. With the parallel political life of the Democratic League of Kosovo, Kosovo Albanians became increasingly aware that ethnic conflict between them and Kosovo's Serbs, who made up less than $10 \%$ of the population, was an awful reality. ${ }^{6}$ Hence, from the end of 1990 until 1997, although Kosovo Albanians offered no military resistance, ethnic tension between Kosovo Albanians, on the one hand, and local Serbs who supported the government in Belgrade, on the other hand, increased significantly. By the end of 1997, ethnic conflict between Albanians and Serbs in Kosovo was inevitable. Albanians looked upon Serbs as rigid supporters of a Belgradeled nationalist invasion against Kosovo Albanians. This, of course, led to the nightmare of conflict between the two ethnic groups in Kosovo, and the feeling that no reconciliation would be possible. This ultimately made Kosovo a divided society. ${ }^{7}$

With the birth of the Kosovo Liberation Army, which comprised the more nationalist Albanian wing, a true war started between the Miloševićled government and Kosovo Albanians. ${ }^{8}$ Milošević unreservedly used his military in offensives against Albanians, which resulted in what was almost universally condemned as genocide against the Kosovo Albanians.

\footnotetext{
5 For a broader view on this issue, see $\mathrm{N}$ Thomas and K Mikulan, The Yugoslav Wars: Slovenia and Croatia 1991-1995 (Osprey Publishing, New York 2006); Hasani, (n 3); Independent International Commission on Kosovo (n 2); N Thomas and K Mikulan, The Yugoslav Wars: Bosnia, Kosovo and Macedonia 1992-2001 (Osprey Publishing, New York 2006). For a more detailed view, see also F Bieber and $Z$ Daskalovski, Understanding the War in Kosovo (Routledge, London 2003).

6 Currently, the ethnic composition of Kosovo, according to the Kosovo Institute of Statistics is: Albanians 92\%, Serbs 5.3\% Turks 0.4\%, Roma $1.1 \%$, and others $1.2 \%$. See Kosovan Statistics Institute, 'Ndryshimet Demografike te popullsise se Kosoves ne periudhen 1948-2006' series no 4. Population Statistics <http://www.ks-gov.net/ESK/index. php?opinion=com_docman\&task=cut_view\&gid=8\&Itemid=8> accessed 15 April 2010.

7 For Kosovo Albanian civil resistance from 1989-1998, see H Clark, Civil Resistance in Kosovo (Pluto Press, London 2000). For the overall circumstances of the war and the factors leading to it, see Thomas \& Mikulan (n 5). See also Bieber \& Daskalovski (n 5).

8 For a detailed argument, see H Papasotiriou, 'The Kosovo War: Kosovar Insurrection, Serbian Retribution and NATO Intervention' (2002) 25 Journal of Strategic Studies 39-62.
} 
This was combined with a policy of ethnic-cleansing. ${ }^{9}$ Consequently, between 1997 and 1999, the division between Kosovo Serbs who, to a greater or lesser extent, supported the nationalist government in Belgrade and Kosovo Albanians that sought independence and freedom from Belgrade became even more problematic.

With the intervention of NATO, Kosovo Albanians assumed the government of Kosovo. Naturally, the Serbian minority felt threatened by the majority. Having been supporters, in one way or another, of official Belgrade policy on Kosovo, Kosovo Serbs took a negative view of the emerging Kosovo Albanian rule over the internationally-administrated Kosovo $^{10}$ and the tension between the two groups increased even more. The Milošević genocide acted as a benchmark for this tension. As a result, during the UN administration of Kosovo, Kosovo Albanians used different means to take revenge on local Serbs. ${ }^{11}$ The end result of the post-war period in Kosovo was that Kosovan society became a rigidly divided one, with Albanians who wanted revenge on one side, and Serbs who still supported Belgrade on the other.

The establishment of the UN-led mission in Kosovo, referred to as UNMIK, and Resolution 1244 of the Security Council affirmed that the international presence in Kosovo was to ensure that it would be a multiethnic society. ${ }^{12}$ The entire international investment in Kosovo during the UN-led administration from 1999-2008 was legitimised by the idea of promoting peace, tolerance and reconciliation between Albanians and Serbs in Kosovo. Since the United States and most European Union members wanted Kosovo to be a state, there was a definite need to find a way to form a state that would somehow be neutral on the question of ethnicity. Hence, the United States, most EU members, and certain other important

\footnotetext{
9 See Stavileci (n 4). For a broader view, see E Stavileci, The Albanian Question at the Crossroads of a Peaceful Solution (the Independent Association of Lawyers of Kosova, Prishtina 1995). See also Judah (n 2); J Marko, 'The new Constitution of Kosovo from the Regional Perspective' (2008) 33 Review of Central and Eastern European Law 437-450.

10 For the role of the UN mission in Kosovo in improving ethnic relations from a legislative perspective, see M Brand, 'Institution-building and Human Rights Protection in Kosovo in the Light of UNMIK Legislation' (2002) 70 Nordic Journal of International Law 461-488.

11 MJ Boyle, 'Revenge and Reprisal Violence in Kosovo' (2010) 10 Conflict, Security and Development 189-216. For a view of Serbia's Foreign Policy on this, see Serbia's Foreign Ministry Comments on 'Technical Assessment of Progress in Implementation of Standards for Kosovo' prepared by the UN GS Special Representative for Kosovo, 30 November 2007 <http://www.mfa.gov.rs/Foreinframe1.htm> accessed 20 July 2010.

12 For a critical view, see I King and W Mason, Peace at any Price: How the World Failed Kosovo (Hurst, London 2006). For the specific challenges facing the UN mission in Kosovo, see $\mathrm{J}$ Friedrich, 'UNMIK in Kosovo: Struggling with uncertainty' in A von Bogdandy and $\mathrm{R}$ Wolfrum (eds), the Max Planck Yearbook of United Nations Law (2005) IX 225-293. For a more practical approach to the Kosovo-UNMIK issue, see L von Carlowitz 'UNMIK Law-making between Effective Peace Support and Internal Self-determination' (2003) 41 Archiv des Volkerrechts 336-393.
} 
world actors opted to make the state of Kosovo a multiethnic one, ${ }^{13}$ thereby acknowledging that the establishment of the Kosovan state favoured neither Albanians nor Serbs. Only in this way, international opinion thought, could the state of Kosovo be internationally acceptable. ${ }^{14}$

Therefore, the UN Envoy for Settling the Status of Kosovo, Marti Ahtisaari, took on the burden of providing a settlement plan to meet this need. Ahtisaari acknowledged that the societal cleavage that existed in Kosovo was an ethnic one but that this cleavage had to be neutralised and removed through the making of a state, thus convincing international opinion that Kosovo's statehood and independence did not only serve Kosovo Albanians, but every ethnic group in the country. As a result, Marti Ahtisaari concentrated his entire settlement plan on accommodating the ethnic cleavage in Kosovo. ${ }^{15}$ By drawing up the settlement plan for Kosovo known as the Ahtisaari Plan, ${ }^{16}$ Marti Ahtisaari affirmed that Kosovo's statehood was based on multiethnic values and that the settlement was aimed at removing the ethnic cleavage in Kosovo. The Ahtisaari Plan was translated into the Constitution of Kosovo, which is considered to be the vehicle for eliminating the ethnic cleavage in Kosovo. ${ }^{17}$ Let us now turn to Kosovo's constitutional law, and observe the solutions that were chosen to address the issue of societal cleavage. ${ }^{18}$

\section{Constitutional design in Kosovo: accommodationist vs integrati- onist approaches}

To begin with, it is worth noting that two competing models of regulation for divided societies exist in theory and practice. To map out the issue of regulation of societal cleavages, theorists are divided into two groups, namely those whose support the accommodation of cleavages

\footnotetext{
13 See the objection of Serbia's Government to this idea in Serbian Ministry for Kosovo And Metohija, 'Comments on the Report of the UN Secretary-General on the United Nations Interim Administration in Kosovo' 1 September-30 November 2007 <http://www.mfa.gov.rs/ Foreinframe1.htm> accessed 20 June 2010.

14 For another explanation on this, see the longer chronology and views in M Weller, 'The Vienna Negotiations on the Final Status of Kosovo' (2008) 84 International Affairs. See also, M Weller, Contested Statehood: Kosovo's Struggle for Independence (OUP, Oxford 2009). For a more general account of the importance of this, see F Bieber, 'Power-sharing as Ethnic Representation in Post-conflict Societies: the Case of Bosnia, Macedonia and Kosovo' in A Mungiu-Pippidi and I Krastev (eds), Nationalism after Communism: Lessons Learned (Central European University, Budapest 2004).

15 See D Kostovicova, 'Legitimacy and International Administration: the Ahtisaari Settlement for Kosovo from a Human Security Perspective' (2008) 15 International Peacekeeping 631-647.

16 Comprehensive Proposal for the Kosovo Status Settlement, UN Doc S/2007/168/Add 1.

17 See the appraisal of the European Commission for the standards of the Constitution of Kosovo as regards the protection of ethnic minorities in Kosovo. Commission Staff Working Document, 'Kosovo under UNSCR1244/99 2008 Progress Report' Commission of the European Communities, SEC (2008) 2697, Brussels.

18 See HH Perritt, The Road to Independence for Kosovo: a Chronicle of the Ahtisaari Plan (CUP, Cambridge 2009); Weller 2009 (n 14).
} 
through power-sharing (accommodationists) and those who seek a model of governance that does not recognise or build upon ethnic cleavages (integrationists). ${ }^{19}$

Accommodationists, on the one hand, support the idea of accommodating ethnic cleavages through recognising the personality of ethnic groups, thereby allowing them to have a reserved place in the executive branch, certain rights of veto, cultural autonomy, etc. The accomodationist model of governance admits the existence of ethnicity in society and polities, and shares power on the basis of it. Therefore, it can be stated that an accommodationist model of governance designs power-sharing on the basis of ethnic cleavages, and guarantees special authority to ethnic groups while allowing no domination by the majority. Thus, accomodationists are those that support and advocate a consociational model of governance..$^{20}$ Integrationists, on the other hand, seek to build a state/ polity that is not divided by means of ethnicity (cleavages), while seeking to create a public identity that stands above ethnic cleavages. From the integrationist perspective, governance must be placed above ethnic cleavages, and the role of the state and the overall identity of the nation and state must not be on ethnic bases. This, in the view of integrationists, will remove the ethnic cleavages and establish a political identity and awareness that is free of strictly ethnic targets. According to integrationists, representation (including that of ethnicities) in political parties and parliament should overcome ethnic division. ${ }^{21}$ Thus, political parties and institutions must be representatives of a single public identity which does not belong to any ethnicity or societal cleavage but is rather above such divisions and prevails over them. ${ }^{22}$

19 J McGarry, B O'Leary and R Simeon, 'The Integration-Accommodation Debate: An Outline' in S Choudhry (ed), Constitutional Design for Divided Societies: Integration or Accommodation? (OUP, Oxford 2008).

20 For a basic view on accommodationism, see A Lijphart, The Politics of Accommodation: Pluralism and Democracy in the Netherlands (University of California Press, LA 1968). For the first attempts to define this issue, see A Lijphart, 'Consociational Democracy', (1969) 21 World Politics 207-225. See also KD McRae (ed), Consociational Democracy: Political Accommodation in Segmented Societies (McClelland \& Stewart, Toronto 1974); A Lijphart, Democracy in Plural Societies (Yale University Press, New Haven 1977); A Lijphart, 'Consociation and Federation: Conceptual and Empirical Links' (1979) 12 Canadian Journal of Political Science 499-515; A Lijphart (ed), Conflict and Coexistence in Belgium: the Dynamics of a Culturally Divided Society (Institute of International Studies, University of California, Berkeley 1981); A Lijphart, Thinking about Democracy. Power-sharing and Majority Rule in Theory and Practice (Routledge, New York 2008).

21 Such political parties can be, for instance, the Labour and Conservative parties in the United Kingdom, which are placed above the ethnic-cleavages of the country, thereby representing no ethnic aim, rather following an integrationist approach to the question of governance.

22 For the integrationist approach as a vehicle of regulation of ethnical divisions, see D Horowitz, A Democratic South Africa? Constitutional Engineering in a Divided Society (Uni- 
Being aware that Kosovo had to be a multi-ethnic state, although $90 \%$ of the population are Kosovo Albanians and less than ten percent are Kosovo Serbs, ${ }^{23}$ the state-builders of Kosovo sought to address the question of regulation of ethnic cleavages in society through the settlement plan. The state-builders wanted to provide a constitutional design for Kosovo that would be able to reach a number of targets. ${ }^{24}$ First, the state-builders knew that Kosovo would need recognition from foreign countries, hence there was a need to promote its multiethnic character as a means of achieving international recognition of its independence. ${ }^{25}$ In this context, the very first target of the constitutional design of Kosovo was to make it an acceptable state to third parties (other states), which was mainly undertaken through accommodating ethnic cleavages and building a model of power-sharing that cast no doubt on its feasibility and the protection of the ethnicities concerned. ${ }^{26}$ The second issue that the statebuilders had to ensure was that the constitutional design ensured that ethnic minorities participated and were over-represented in public life as a means of convincing international opinion that the new state was one for all ethnicities and was not constituted on the basis of discrimination or other forms of inequality. ${ }^{27} 2829$ Third, the state-builders had to see if

versity of California Press, LA 1991); B Barry, Culture and Inequality (Polity Press, London 2000). The initial view on these sources has been taken from J McGarry and B O'Leary, 'Iraq's Constitution of 2005: Liberal Consociation as Political Prescription' (2007) 5 International Journal of Constitutional Law 670-698.

${ }_{23}$ See AC Kupchan, 'Independence for Kosovo: Yielding Balkan Reality’ (2005) 82 Foreign Affairs 14-20.

24 The Commission for Drafting the Constitution of Kosovo had a multiethnic composition, and a huge international presence observed the drafting process. See Decree of the Kosovan President on the appointment of the Kosovan Constitutional Commission, 19 February 2008 at <http://www.kosovoconstitution.info/repository/docs/VENDIMI\%20I\%20PRESIDENTIT\%20per\%20KKK.pdf> accessed 30 March 2010. See also J Tunheim, 'Rule of Law and the Kosovo Constitution' (2009)18 Minnesota JIL 371.

25 See C Warbrick and D McGoldrick 'Kosovo: The Declaration of Independence' (2008) 57 ICLQ 675-690. For the harmony between the Ahtisaari Settlement and the Constitution of Kosovo, see the Press Release of the Constitutional Commission of Kosovo regarding Peter Faith's decision on the Certification of the Kosovan Constitution, 2 April 2008 at <http:// www.kushtetutakosoves.info/?cid=1,203,1316> accessed 25 March 2010. See also the Press Statement of the Second Meeting of the International Steering Group (ISG) for Kosovo, 17 April 2008 para 4 Vienna.

26 During the constitutional drafting process, this need was made explicit to everyone. See, Tunheim (n 24) 371-379.

${ }_{27}$ For the special guarantees for ethnic minorities, see J Marko (n 9). For a broader view on this issue, see Weller 2009 (n 14). For the focus of the Ahtisaari Settlement in this context, see Perritt (n 18).

28 Many argue that domestic assent for the extensive presence of human rights guarantees for ethnic minorities has been given to ensure that international conditionality over Kosovo results in a successful mission, thereby allowing the international community to support Kosovo's independence. For an introductory view on this, see B Rechel, 'Introduction' in B Rechel, (ed) Minority Rights in Central and Eastern Europe (Routledge, New York 2009).

29 Some, for instance, are of the view that the broad privileges for ethnic minorities were aimed at making minorities accept the idea of Kosovo's independence. See Kostovicova (n 15). 
the choices made conformed to both the standards of accommodation of ethnic minorities and, most importantly, the new state's political sustainability. Though many authors have spoken with a lot of enthusiasm of the exceptional character that a pure accommodationist approach to state-building can create, the Ahtisaari Commission was more realistic in this regard. When looking at the choices made in a similar international state-building process in Bosnia and Herzegovina, which culminated in the Dayton Agreement settlement and its constitutional product, one can observe that a very rigid consociational constitutional design has produced an almost failed state with separatist tendencies and segmented policy-making that leads to government malfunctioning. ${ }^{30}$ This third issue, in our view, was the most important matter that the Ahtisaari Commission had to face, as it wanted a state of Kosovo that was multi-ethnic but that does not face the survival challenges that Bosnia and Herzegovina does. To address this issue, the Ahtisaari Commission had to be very careful when selecting constitutional design choices, acknowledging that there would be a combination of accommodationist and integrationist approaches. We will be arguing that there is a very broad presence of consociational elements in Kosovo's constitutional design. However, the Ahtisaari Commission was very careful to allow (though barely discernibly) integrationist elements at the heart of Kosovo's constitutional design in order to ensure the polity's political stability and guarantee a sustainable state. In arguing and building upon this, we shall approach the issue of the elements of the constitutional design of Kosovo by examining and applying both the accommodationist and integrationist approaches.

Though many would say that the essential feature of Kosovo's constitutional design is its extensive consociational nature ${ }^{31}$ (although there is practically no article that seriously discusses this), including our earlier article on this issue, ${ }^{32}$ we are of the view that the consociational character of Kosovo's constitutional law does not hinder the integrationist character of the central aspects of the polity. However, in order to argue this, one must survey the constitutional law of Kosovo. We will organise the survey on the grounds of the theory of consociationalism. We will examine Arend Lijphart's four elements of a consociational polity with regard to the constitutional design of Kosovo, namely: 1) the power-sharing

\footnotetext{
${ }_{30}$ For state failure in Bosnia, see 'From Dayton to Dysfunction: Five Numbers that Suggest Bosnia is Becoming a Failed State' Newsweek at <http:/ /www.newsweek.com/2009/10/14/ from-dayton-to-dysfunction.html> accessed 15 October 2009.

31 For this reason, the European Commission has appreciated the high standard of the Constitution of Kosovo. See Commission of the European Communities (n 17).

32 See D Doli and F Korenica, 'What about the Kosovo Constitution: Is there Anything Special? Discussing the Grundnorm, the Sovereignty and the Consociational Model of Democracy' (2010) Working Paper no 03/2010 Group for Legal and Political, Prishtina.
} 
executive (grand coalition government), 2) proportionality, 3) veto rights, and 4) cultural autonomy. ${ }^{33}$

To start with, let us illustrate some of the consociational proclamations of the Constitution of Kosovo, which, though having no importance in practice, are significant for the symbolic nature of Kosovo's polity. Consociational elements of the Constitution of Kosovo of a symbolic nature include (as proclaimed by the Constitution): a) Kosovo is a multiethnic state ${ }^{34}$ b) Kosovo is a state of its citizens, without reference to ethnicity or any single ethnic group; ${ }^{35} \mathrm{c}$ ) official languages at the central level shall be Albanian and Serbian, while every other minority language will have official language status at the local level;37 d) minorities will have advanced human rights status; ${ }^{38}$ e) Serbian ethnicity has special cultural heritage protection ${ }^{39}$ (aimed at protecting Serbian churches), f) Kosovo's flag, anthem and coat of arms will be multiethnic, or at least neutral regarding the question of ethnicity, ${ }^{40}$ etc. ${ }^{41}{ }^{42}$

\subsection{The power-sharing executive (grand coalition government)}

Since the Kosovo system of government has a bicephalic executive branch, two issues must be examined here: a) power-sharing in the formation of governments; b) the nature of power-sharing in the context of the head of state (the President of the Republic).

In terms of government formation and design, the Constitution of Kosovo sets out that the government must contain, inter alia, at least two ministers who represent the ethnic minorities in Kosovo, one of whom

\footnotetext{
33 For more on this, see Lijphart 2008 (n 20) and 1968 (n 20). For the origin of this, see Lijphart 1969 (n 20).

34 Constitution of the Republic of Kosovo 2008, art 3, para 1.

35 Constitution (n 34) art 1, para 2.

36 The citizenship regime of the Constitution of Kosovo follows a multiethnic and inclusive approach which is purely consociational in nature. See G Krasniqi, "The Challenge of Building an Independent Citizenship Regime in a Partially Recognized State: the Case of Kosovo' (2010) CITSEE Working Papers Series, paper no 04 <http://www.law.ed.ac.uk/ citsee/workingpapers> accessed 15 August 2010.

37 Constitution (n 34) art 5, para 1.

38 Constitution (n 34), art 57, para 1. See also E Lantschner, 'Protection of Minority Communities in Kosovo: Legally Ahead for European Standards - Practically Still a Long Way to Go' (2008) 33 Review of Central and East European Law Review 451-490.

39 Constitution (n 34) art 9.

40 Constitution (n 34) art 6 para 1.

41 For a broad catalogue of privileges guaranteed to ethnic minorities in Kosovo, see O Tansey, 'Kosovo: Independence and Tutelage' (2009) 20 Journal of Democracy 153-166.

42 For the municipal human rights instruments guaranteed to Serbs in Kosovo, see G Krasniqi, 'Local Policies in Multiethnic Communities' (2009) KIPRED's Civil Dialogue Working Paper Series, Prishtina.
} 
must come from the Serbian ethnic group. ${ }^{43}$ This constitutional provision, runs the argument, is a consociational one, since it requires a grand coalition government consisting of those who have a majority in parliament and two other minority ministers, regardless of their party/ group's seats. It is therefore argued that the membership of Kosovo's government is unquestionably consociational. For example, currently there are three incumbent minority ministers, two of whom are Serbian. ${ }^{44}$ It is therefore clear that membership of the government of Kosovo follows a consociational rationale, accommodating ethnic minorities through reserved places in the government irrespective of seats in parliament. This picture leads to the view that the government of Kosovo is a grand coalition government in the ethnic representation context. However, in order to examine whether this picture is purely consociational, two additional questions need to be asked. First: Do ethnic-minority ministers in the government have a right of veto in government decision-making? Second: Does the prime minister hold any constitutional power to direct the work of minority ministers? In answer to the first question, as laid down in the Constitution, minority ministers have no right of veto in the decisionmaking of the government. ${ }^{45}$ This means that minority ministers in the government, though sitting in reserved seats, have no means of blocking the decision-making process in the government. This suggests that the Constitution sees the governmental decision-making process as being purely integrationist in nature, given that no assurance that minority ministers' interests will be included in policy is constitutionally provided for. In response to the second question, it is necessary to ask if minority ministers can have autonomy from the prime minister while performing their ministerial duties. The Constitution of Kosovo clearly authorises the prime minister to direct the work of every minister, including minority ministers ${ }^{46}$ In addition, the Constitution provides the prime minister with the power to change a minister without the assent of parliament. ${ }^{47}$ Consequently, it can be argued that the Constitution provides for a pure integrationist approach when it comes to the direction of the work of minority ministers, their dismissal and appointment. A third point is that the appointment of minority ministers is not carried out independently by ethnic minority MPs. Instead, the majority of all members of parliament must confirm their appointment (as part of the entire government team). Hence, given that ethnic minority ministers are appointed in the

\footnotetext{
43 Constitution (n 34) art 96 para 3.

44 'New Mandate, New Opportunities', Report of the National Democratic Institute, October 2008, Prishtina.

45 The Constitution of Kosovo allows no veto right for ethnic minority ministers in the government. See the section on the government in the Constitution (n 34).

46 Constitution (n 34) art 94 paras 1 and 2.

47 Constitution (n 34) art 94 para 4.
} 
usual manner, and since ethnic minority MPs have no right to appoint them independently, the manner of appointing the ministers concerned is certainly integrationist in nature. Thus, runs the argument, ethnic minority ministers are bound not only to ethnic minority MPs, but also to the entire parliament, given the parliamentarian nature of Kosovo's system of government. In addition, given that the government is appointed by a majority of the members of parliament, which is dominated by Albanian MPs (85\%), it can be argued that the process of government formation can be undertaken without the votes of minority MPs. This, of course, furthers the idea that the formation of a grand coalition government can go beyond ethnic interests and no ethnicity can block the process. The three points examined above are significant in terms of the question of the accommodationist-integrationist debate. In conclusion, one can assert that only the membership of the government of Kosovo accommodates ethnic minorities and therefore has a consociational character. However, the way decisions are made in the government, the powers that the prime minister has over his/her ministers, and the way ethnic minority ministers are appointed illustrate a rather integrationist nature of government. For this reason, government in this form delivers both political sustainability and governmental unity with no likelihood of ethnically-based blocking of policies.

The second significant issue in this section is the character of the President of the Republic in light of the accommodationist-integrationist debate. In contrast to Bosnia and Herzegovina, ${ }^{48}$ which has a collective president of the Republic consisting of three members, one for each ethnic group, ${ }^{49}$ the international state-builders of Kosovo were careful to constitutionally establish a president that had no likelihood of failure/ being blocked by ethnic instruments, while at the same time allowing for certain consociational elements. To this end, the Constitution of Kosovo provides for an individual President of the Republic, meaning that only one person holds Kosovo's presidency. In addition, the Constitution prescribes that: 'The President is the head of state and represents the unity of the people of the Republic of Kosovo'. ${ }^{50}$ Hence, one can argue that the Constitution, on the one hand, authorises this individual president to be the head of state, but also makes the president a figure of national unity on the other. Being a figure of national unity, therefore, is an anti-majoritarian signal, signifying that the President of the Republic represents both the majority and minorities of the state while leaving aside the question of ethnicity.

\footnotetext{
48 For the constitutional system of Bosnia and Herzegovina and its legal and political challenges, see S Yee, 'The New Constitution of Bosnia and Herzegovina' (1996) 7 EJIL 176-192.

49 See the Constitution of Bosnia and Herzegovina <http://www.ccbh.ba/public/down/ USTAV_BOSNE_I_HERCEGOVINE_engl.pdf> accessed 1 June 2010.

50 Constitution (n 34) art 83.
} 
Since the Constitution provides for an individual President of the Republic, as opposed to a collective head of state like that of Bosnia and Herzegovina, one can argue that the President of the Republic is established on a purely integrationist basis. Therefore, one can claim that the President of the Republic is unrestrained in his/her policies, and that he/she is preconditioned to act above ethnic interests, thereby representing a single identity of the country while disregarding power-sharing along ethnic lines. However, in order to conclude this argument, one can examine the procedure of appointing the president, since this might change the character of the institution. According to the Constitution, the president is elected in the third round by a majority of votes in the parliament. ${ }^{51}$ In view of this, there is no possibility of any ethnic group blocking the election of the president, as opposed to qualified majority voting or double majority voting procedures. This supports the argument about the integrationist nature of the President of the Republic.

On the other hand, in order to provide the institution of the President of the Republic with a consociational element, the Constitution of Kosovo sets out that: 'A Consultative Council for Communities acts under the authority of the President of the Republic of Kosovo in which all Communities shall be represented'. ${ }^{52}{ }^{53}$ The Consultative Council for Communities promotes the interests of ethnic groups in the law-making and policy-making process under the authority and influence of the President of Republic. The Council, therefore, softens the integrationist nature of the President of the Republic, and allows ethnic communities to be accommodated. This solution clearly dismisses any possibility of an ethnic minority veto in the work of the head of state (unlike the example of Bosnia and Herzegovina). However, all ethnic minorities are represented and their interests are acted upon through the constitutional design of the President of the Republic. To sum up, one can argue that the Constitution of Kosovo has established an integrationist President of the Republic with certain consociational features. This constitutional choice clearly removes the problems concerning the functioning of the head of state that have appeared in Bosnia and Herzegovina. ${ }^{54}$ At the same time, it allows ethnic minorities to have a fundamental say through the context of the head of state.

In addition to the central government, it is worth noting that the Ahtisaari Plan, which is a constitutionalised document, allows the Ser-

\footnotetext{
51 Constitution (n 34) art 86 para 5.

52 Constitution (n 34) art 60 para 1.

53 This is in line with the so-called Lund Recommendations. See OSCE High Commissioner on National Minorities, 'Lund Recommendations on the Effective Participation of National Minorities in Public Life' September 1999 p 24 <http:/ /www.osce.org/documents / hcnm/1999/09/2929_en.pdf> accessed 27 July 2010.

54 In support of this, see Marko (n 9).
} 
bian community in Kosovo to be vested with special local governmental powers. In fact, through a very broad plan of decentralisation which has afforded local Serbian communities special communal rights, the international state-builders added a number of new municipalities in Kosovo, consisting of mainly Serbs, stating that the decentralisation process aimed to 'ensure that most Serbs would live in majority-Serb municipalities'. ${ }^{55}$ This has allowed local Serbs in Kosovo to take advantage of the local self-rule vested through the process of ethnic decentralisation, which has led to Kosovan Serbs engaging with the local authorities. ${ }^{56}$ In addition, this form of decentralisation has granted local Serbs self-rule as regards their municipal governance, thus disengaging from larger Albanianled municipalities. The form of decentralisation provided for the Serbian community, though purely consociational, has provided Serbs with the capacity to direct their own municipal life by being autonomous from the Albanian majority.

\subsection{Proportionality}

Proportionality is another principle of a consociational polity. Proportionality refers to the proportional representation of ethnic groups in the parliament, public administration, judiciary, army, police service, and other state services including state-owned firms. Many consider that the principle of proportionality has been exceeded in the constitutional design of Kosovo. However, we will examine this principle within the context of the larger accommodation-integration debate. To begin with, the principle of proportionality can be observed in at least four segments of constitutional design: the composition of parliament; the electoral system; the composition of the judiciary; employment in the state/public administration and state-owned firms.

First, the Constitution of Kosovo sets out that:

\footnotetext{
55 Tansey (n 41) 159.

56 See the European Union's appreciation of Serbian participation in local government elections in 'European Parliament resolution on the European integration process of Kosovo', European Parliament Document B7-0409/2010 <http://www.eusrinkosovo.eu/d/ resolution $\% 20$ on $\% 20$ the $\% 20$ European $\% 20$ integration $\% 20$ process $\% 20$ of $\% 20$ Kosovo.pdf $>$ accessed 5 June 2010; Kosovar Institute for Policy Research and Development, 'Review of Decentralization - Functioning of Serb Majority Municipalities' (2010) Policy Brief no 2010/5 Prishtina <http://kipred.net/web/upload/Review_of_Decentralization.pdf> accessed 8 June 2010; Kosovar Institute for Policy Research and Development, 'Decentralization in Kosovo I: Municipal elections and the Serb participation' (2009) Policy Brief no 2009/15 Prishtina <http://www.kipred.net/web/upload/Decentralization_in_Kosovo_I. pdf> accessed 5 July 2010; Kosovar Institute for Policy Research and Development, 'Decentralization in Kosovo II: Challenges of Serb majority municipalities' (2009) Policy Brief no 2009/16 Prishtina <http://www.kipred.net/web/upload/Decentralization_in_Kosovo_ II.pdf $>$ accessed 8 July 2010.
} 
The Assembly has one hundred twenty (120) deputies elected by secret ballot on the basis of open lists. The seats in the Assembly are distributed amongst all parties, coalitions, citizens' initiatives and independent candidates in proportion to the number of valid votes received by them in the election to the Assembly. ${ }^{57}$

One basic argument thus applies, namely that the electoral system will be proportional in line with Article 64 of the Constitution. In addition, Article 64 sets out that 'twenty (20) of the one hundred twenty (120) seats are guaranteed for representation of communities that are not in the majority in Kosovo'. ${ }^{58}$ Thus, one can argue that the Constitution not only provides for proportional representation at the parliamentary level for all ethnic groups, but that it also establishes the principle of reserved seats for ethnic minority representation in the parliament. Consequently, the Constitution sets forth a protection mechanism for ethnic minority representation in parliament, which, even if ethnic minorities refuse to vote in elections, guarantees them seats in parliament. This mechanism is purely consociational in nature, since it ensures that no legislature can exist without at least 20 minority MPs, regardless of whether the ethnic minorities turned out in the election or not. In addition, the Constitution reserves seats for two deputy speakers of the Parliament from ethnic minority representatives. ${ }^{59}$ Thus, besides the proportional electoral system set out by the Constitution, which clearly protects ethnic minorities from majoritarian rule, the Constitution allows for a mechanism that accommodates ethnic minorities in parliament (through guaranteed seats) even though they might refuse to participate in elections. Overall, the constitutional solution of a purely proportional electoral system, on the one hand, and guaranteed seats for ethnic minorities (regardless of the number of votes cast by the minorities concerned) on the other, leads to the conclusion that the proportionality principle in the context of parliament's composition and the electoral system is purely consociational.

Second, the Constitution of Kosovo allows very wide representation of minority judges and prosecutors in Kosovo. In the first case, the Constitution provides for over-representation of minorities in the Constitutional Court of Kosovo, where, of nine judges, two come from ethnic minorities, one of whom must come from the Serbian minority. A double majority, that is the majority of the entire parliament and a majority of MPs representing ethnic minorities, is used to elect the two ethnic minority constitutional judges. ${ }^{60}$ In addition, at least $15 \%$ of the judges of the Supreme Court of the country, but not less than three, come from

\footnotetext{
57 Constitution (n 34) art 64 para 1.

58 Constitution (n 34) art 64 para 2.

59 Constitution (n 34) art 67 para 4.

60 Constitution (n 34) art 144.
} 
ethnic minorities. ${ }^{61}$ The same formula is used in the composition of every other court in the country. ${ }^{62}$ The same rule is also applied in the recruitment and appointment of prosecutors. ${ }^{63}$ Thus, in terms of composition, the Constitution provides for a judiciary and Constitutional Court with reserved seats for ethnic minority judges, which clearly over-represents them in the judiciary. However, one might ask whether the decision-making process within the judiciary (in any court) and in the Constitutional Court $^{64}$ allows any room for a veto from minority judges. This, of course, is fully opposed by the Constitution, and there is no room for such options. It therefore leads to the conclusion that although the principle of the over-representation of ethnic minority judges in the judiciary and Constitutional Court is apparent, the form of decision-making and appointment by the Judicial Council clearly favour an integrationist judiciary. ${ }^{65}$

Third, the Constitution applies the principle of proportionality in the public administration and state-owned enterprises. It states that:

Communities [ethnic minorities] and their members shall be entitled to equitable representation in employment in public bodies and publicly owned enterprises at all levels, including in particular in the police service in areas inhabited by the respective Community, while respecting the rules concerning competence and integrity that govern public administration. ${ }^{66}$

Hence, one can claim that the principle of proportionality applies to public administration and state-owned enterprises. This suggests that employment in the public sector in Kosovo is largely consociational, at least in terms of reserved places for ethnic minority members.

In conclusion, given that the Constitution provides for additional guaranteed seats for ethnic minorities in the Judicial Council of Kosovo, ${ }^{67}$

61 Constitution (n 34) art 103 paras $1-3$.

62 Constitution (n 34) art 103 para 6.

63 Constitution (n 34) art 110.

64 The preliminary discussions for the Bosnian Constitutional Court raised the idea of allowing veto rights for every ethnic community judge in the Bosnia and Herzegovina Constitutional Court. This has largely been opposed by the Venice Commission, which sees it as a tendency to make the Constitutional Court an institution advocating ethnic issues rather than promoting the constitutional rule of law. This problem, however, is not apparent and has not been an option for international state-builders in Kosovo. See the case of Bosnia in 'Opinion no 344/2005 on Proposed Voting Rules for the Constitutional Court of Bosnia and Herzegovina', European Commission for Democracy Through Law (Venice Commission) CDL-AD (2005) 039 Strasbourg 8 November 2005.

65 For the appointment of judges, see Constitution (n 34) art 108.

66 Constitution (n 34) art 61.

67 Constitution (n 34) art 108 para 6. 
the Central Electoral Commission, ${ }^{68}$ the Kosovo Security Force, ${ }^{69}$ the local government ${ }^{70}$ etc, one can claim that the principle of proportionality is employed in Kosovo's system of government, ${ }^{71}$ and that this is probably the purest consociational aspect of the state of Kosovo.

\subsection{Veto rights}

A veto right is the third component of a consociational polity. This right consists of the power of certain ethnic groups to either block directly or suspend the taking of a decision, adoption of a law or enactment of a policy. In the Kosovan context, the veto right of ethnic minorities is provided for by the Constitution in two cases, namely the right of veto on constitutional amendment procedures, and the right of veto on the adoption of so-called vital laws and amendment procedures.

First, the Constitution states that:

Any amendment shall require for its adoption the approval of two thirds (2/3) of all deputies of the Assembly including two thirds (2/3) of all deputies of the Assembly holding reserved or guaranteed seats for representatives of communities that are not in the majority in the Republic of Kosovo. ${ }^{72}$

By means of Article 144.1, the Constitution of Kosovo has vested ethnic communities with the right of vetoing the constitutional amendment process if it in their view needs to be stopped. This model of veto is both direct and absolute, meaning that it cannot be suspended or revoked at a later time. The right of veto over the constitutional amendment process makes the ethnic communities of Kosovo a constituent part of this constitutional process, therefore acknowledging that no constitutional change can be undertaken without their assent. It goes without saying that the ethnic minorities concerned have been granted an important position as regards the protection of the current constitutional order and its consociational elements by Article 144 .

The veto right in the constitutional amendment process acknowledges that no constitutional change can be undertaken if the ethnic communities that form part of the ethnic minority groups in parliament refuse to vote for it. This certainly suggests that constitutional change in Kosovo is rather difficult, since neither a single community nor the majority in parliament can make a constitutional change without a double majority.

\footnotetext{
68 Constitution (n 34) art 139 para 4.

69 Constitution (n 34) art 126 para 4.

70 Constitution (n 34) art 62 para 1.

71 On the over-representation of minorities in the Kosovan system of government, see Marko (n 9).

72 Constitution (n 34) art 144 para 1.
} 
This feature certainly contributes to the rigid character of the Constitution of Kosovo, and shows that it is rather difficult to make constitutional revisions. However, one might ask what the rationale for the rigid nature of the Constitution of Kosovo is. The most basic argument that can be put forward is that it has been designed as a mechanism to ensure that constitutional changes only take place if every ethnic community, both the majority and minorities, agrees. This supports the argument that the rigid character of the Constitution of Kosovo was designed for consociational purposes. Besides offering no way of altering the Constitution without the assent of each ethnic community, this constitutional solution ensures that the consociational components of the Constitution of Kosovo are mandatory for the polity and that no way of revoking them exists. In conclusion, the international state-builders of Kosovo, by building a system of constitutional rigidity, have ensured that the constitutional system not only provides a privileged position for ethnic minorities, but that the right to change this position belongs to both the majority and minorities. Thus, a system has been ensured which upholds the constitutional rights concerned. However, this veto right could not be exercised upon the adoption of the Constitution, as it did not have effect at the time the Constitution was drawn up. One can see in this an integrationist argument, which asserts that the adoption of the Constitution had an integrationist character, as there was no minority veto for the first adoption of the Constitution.

Second, the Constitution of Kosovo has vested minorities with the power to veto the adoption, amendment and repeal of so-called vital laws. ${ }^{73}$ The Constitution states that:

The following laws shall require for their adoption, amendment or repeal both the majority of the Assembly deputies present and voting and the majority of the Assembly deputies present and voting holding seats reserved or guaranteed for representatives of Communities that are not in the majority:

(1) Laws changing municipal boundaries, establishing or abolishing municipalities, defining the scope of powers of municipalities and their participation in intermunicipal and cross-border relations;

(2) Laws implementing the rights of Communities and their members, other than those set forth in the Constitution;

(3) Laws on the use of language;

(4) Laws on local elections;

(5) Laws on protection of cultural heritage;

73 See Tansey (n 41). 
(6) Laws on religious freedom or on agreements with religious communities;

(7) Laws on education;

(8) Laws on the use of symbols, including Community symbols and on public holidays.

2. None of the laws of vital interest may be submitted to a referendum. ${ }^{74}$

Having read the prescription of the Constitution, one can raise three questions, namely: a) What is the degree of veto that ethnic communities can exercise? b) What is it designed for? c) Does the veto concerned constitute the right to block laws? Certainly, ethnic communities have been given the right to veto laws of vital interest. However, other laws need no double majority for their repeal, amendment or adoption. Thus, the degree to which a veto over laws can be used by ethnic minority representatives is rather limited. On the other hand, one could argue that the veto right on vital laws provided for is both direct and absolute. However, can one put a vital law to a referendum if ethnic minorities continuously block the process of adoption, amendment or repeal? Article 81 of the Constitution certainly allows no room for referendum on laws of vital interest, thus signifying that ethnic minority MPs' veto cannot be overcome by a referendum. This leads to the suggestion that veto right on laws of vital interest is constitutionally made to be sustainable and purely consociational, thus allowing no form of majority rule to come into place through a referendum, which would also revoke such a veto. This suggestion, therefore, acknowledges that the right to veto laws of vital interest certainly cannot be overcome by any single ethnic group, say Albanians, which points to the idea that its design is purely consociational. However, what is the rationale of this veto? When reading Article 81 , one can see that vital interest laws are of a consociational character. Each law mentioned in Article 81, establishes privileges and prohibitions that stand as guarantees of ethnic minorities' constitutional position. Therefore, laws of vital interest are those laws that are aimed at protecting ethnic minorities. In view of this, one can argue that the right to veto laws of vital interest allows ethnic communities to have a constitutive position, sine qua non, where the adoption, amendment and repeal of laws that touch the very character of the consociational nature of Kosovo's polity is concerned. However, it can be argued that the vital laws which the Constitution speaks of are not the most important laws of the polity. Such laws, one might argue, are those that set the legal basis for the functioning of the government, parliament, police, army, public administration, parliamentary elections, president, and so on. Therefore, one can say that the con-

74 Constitution (n 34) art 81. 
sociational scope of the right to veto laws of vital interest applies to the field of the culture/identity of the ethnic communities concerned, while the laws that have the most importance for the polity can be adopted, amended or repealed without the ethnic minorities' vote.

To sum up, one can assert that the right to veto the constitutional amendment process is significant for the existence of the polity and the overall political system. This, therefore, can be considered a pillar of the consociational nature of Kosovo's constitutional regime. However, the impossibility of ethnic communities vetoing the adoption of the Constitution nevertheless suggests that the Constitution was adopted under an integrationist umbrella. In addition, to a certain extent, one can also speak about the right of veto over laws of vital interest as a consociational element of the polity, though acknowledging that this idea is limited to the extent that its application does not touch laws that sustain the very bases of the polity.

\subsection{Cultural autonomy}

Cultural autonomy is the fourth element of a consociational polity. It consists of ethnic minorities being given special cultural protection through the provision of autonomy to deliver their own identity-protection mechanism. The Constitution of Kosovo, as a result, allows rather broad cultural autonomy for each ethnic minority. In order to be concise in this context, we shall briefly illustrate this component in the context of Kosovo's constitutional regime.

Cultural autonomy for ethnic minorities under the Constitution of Kosovo consists of: a) allowing ethnic minorities, especially Serbs, to use their language at each level, while granting the Serbian language the status of official language at every level; $;^{75} \mathrm{~b}$ ) state symbols being multi-ethnic in nature, thus allowing each ethnic minority to find itself represented in the state symbols; ${ }^{77} \mathrm{c}$ ) ethnic minorities' religious monuments receiving special protection from the state, with Serbian Orthodox churches being granted exterritorial status in their territories ${ }^{78} \mathrm{~d}$ ) ethnic minorities having the right to be educated in their language, which right is broad and very substantial ${ }^{79}$ e) ethnic minorities having the right to use their alphabet in relations with the government and on their identification documents; $; 0$ f) ethnic minorities having the right to have their street names in their lan-

75 Constitution (n 34) art 5 paras 1 and 2. See also Kosovo's Law No 02/L-37 on the Use of Languages.

76 For the quality of this standard, both legally and practically, see Lantschner (n 38).

77 Constitution (n 34) art 6 para 1.

78 Constitution (n 34) art 39 para 1.

79 Constitution (n 34) art 59 paras 1 and 2.

80 Constitution (n 34) art 59 para 6. 
guage and according to their choice; ${ }^{81} \mathrm{~g}$ ) ethnic minorities having reserved places on every public media programme ${ }^{82}$ in addition to having their own public broadcasts in the Serbian language, ${ }^{83}$ etc.

Overall, one can say that the consociational element of cultural autonomy in Kosovo is firmly employed. Thus, one can speak of ethnic minorities having certain and broad culturally-autonomous authority. Although this is in line with consociationalism, the integrationist character of this cultural policy is nevertheless promising, since a part of the cultural elements of the state of Kosovo stand above ethnic interests, and thus represent Kosovo's identity as a state freed from ethnicity and neutral in terms of ethnic allegiance.

\section{A critique of the existence of both consociational and integratio- nist elements in the Kosovo polity}

One might look at the nature of Kosovo's polity and see that its consociational and integrationist elements have a complementary harmony. However, it is obvious that certain criticisms exist in this regard. One criticism claims that Kosovo cannot be in reality a consociational polity due to the challenges that it faces, while another criticism argues that an integrationist approach cannot be made reality in Kosovo due to the problem of majority rule and its monoethnic character. We shall engage with these two criticisms and allow the reader to comprehend the nature of the problem with Kosovo's constitutional regime.

As far as the first criticism is concerned, many consider that the consociational elements in Kosovo's constitutional regime will not work, since there is no vibrant ethnic minority any more in Kosovo which would be engaged and assume power-sharing. ${ }^{84}$ This argument is based upon the presumption that ethnic minorities, and most importantly Kosovan Serbs, have no will or political vibrancy to make them accept and work within a consociational Kosovo. Hence, runs the argument, since ethnic minorities, and most importantly Serbs, take no active part in public life, the consociational elements of Kosovo's polity have no rationale within this reality, given that there in no Serbian-led group that is actively taking advantage of them. This criticism, one would say, is directed at those who claim that Kosovo is a consociational polity. The criticism as

\footnotetext{
81 Constitution (n 34) art 59 para 9.

82 Constitution (n 34) art 59 para 10.

83 Constitution (n 34) art 59 para 11.

84 J Hughes, 'EU Conflict Management Policy: Comparing the Security-development Model in the 'Sui Generis' Cases of Northern Ireland and Kosovo' (2009) paper presented at the European Consortium for Political Research 10-12 September 2009 Potsdam, Germany <http://eprints.1se.ac.uk/26061/> accessed 1 August 2010.
} 
such, is rather logical and has some relevance to the current situation. ${ }^{85}$ However, we would disagree, arguing that the consociational system of governance in Kosovo works, ${ }^{86}$ and that its intention has already been almost accomplished. There are at least three arguments in response to the first criticism. First, the most important indicator to measure this is the effectiveness of Ahtisaari's decentralisation reforms. Though local Serbs refused for a long time to take part in Kosovo's local elections, ${ }^{87}$ in the last local elections Kosovo Serbs participated in the electoral process as active voters. ${ }^{88}$ In addition, Serbian local parties in Serbian municipalities have proved very active in political campaigning, allowing the claim to be made that Serbian party politics in Kosovo is being established. Hence, though in the last local elections Serbs did not turn out to vote in every self-government Serbian municipality, they did so in most of them, thus demonstrating that the Serbian electorate and parties have made use of the consociational power-sharing that Kosovo's constitutional regime has offered them. ${ }^{89}$ Secondly, Serbian political parties currently hold two Kosovan Government ministries, ${ }^{90}$ and most assessment reports indicate that the Serbian ministers in the Kosovan Government are very active and have taken a respected position in the government coalition. In addition, there is evidence that shows that the Serbian political parties in Kosovo that participate in parliament have a responsive relationship with the Prime Minister, ${ }^{91}$ demonstrating that active Serbian party politics at the governmental level is now a reality in Kosovo. Such a view is also shared by the head of the government. ${ }^{92}$ Thirdly, Serbian political parties in Kosovo, both at the national and local level, have lately refused and clearly

85 See some of the challenges to this system in 'Freedom in the World Country Report 2009', Freedom House <http:/ / www.freedomhouse.org/template.cfm?page $=22 \&$ country $=7$ 757\&year=2009)> accessed 16 July 2010; See also 'Kosovo under UNSCR1244/99 2009 Progress Report', Commission Staff Working Document, Commission of the European Communities, SEC (2009) 1340 Brussels.

86 To see how the claim of an ethnic minority in Kosovo has been affirmatively judged, although anti-majoritarian in nature, by Kosovo's Constitutional Court, see Case KO01/09 Qemajl Kurtisi vs Municipal Assembly of Prizren AGj07/10 Constitutional Court of Kosovo 18 March 2010. See also how the international presence in Kosovo appreciates the decision of the Constitutional Court, and affirms its aim of offering special protection to minorities in Kosovo in 'Ruling of Constitutional Court Supports Community Rights' ICR News Release No 04/2010 of 24 March 2010 <http://www.-kos.org/2/100319_CC_PRIZREN_emblem_ eng.pdf $>$ accessed 15 April 2010.

87 See Freedom in the World Country Report 2009 (n 85).

88 See Kosovar Institute for Policy Research and Development (n 56).

89 See 'Kosovo Prime Minister Statement Addressing the International Steering Group on Kosovo' 8 February 2009 Vienna <http: / / www.kryeministri-ks.net/?page=2,104,1133> accessed 5 August 2010.

90 National Democratic Institute (n 44).

91 'Minister Rašić and Prime Minister Thaqi Laid the Cornerstone for the House of a Serbian Returnee Farm' Kosovo Ministry of Communities and Returnees Official Website, news section <http://mkk-ks.org/?page=2,12,132> accessed 15 August 2010 .

92 See 'Kosovo Prime Minister Statement Addressing the International Steering Group on Kosovo’ (n 89). 
rejected the idea of following Belgrade's directives. ${ }^{93}$ This clearly signifies that Serbian political parties in Kosovo are making progress in establishing a political identity that rejects the idea of being led by nationalist directives from Belgrade, while at the same time representing local Serbian interests both in the Government of Kosovo and in local government institutions. The role of the international presence in Kosovo in facilitating this process has thus far proven very successful and is a guarantee of its credibility. ${ }^{94}$ Therefore, all three arguments clearly counter the criticism that there is no longer any vibrant Serbian community in Kosovo to make use of the consociational components of Kosovo's polity, thus proving that Serbs in Kosovo are progressing and have clearly achieved a political vibrancy that points to the success of the constitutional regime.

On the other hand, many political actors have strongly criticised the integrationist elements in Kosovo's constitutional regime. They argue that it can be spoken of only in terms of Albanian-led governance and not integrationist elements in Kosovo's polity. Such views have been promoted by Serbia's foreign policy, which has held that Kosovo's polity is an Albanian one, ${ }^{95}$ and not one of an integrationist character that transcends ethnic interests. This view also holds that international state-building in Kosovo has produced a political system that only achieves the Albanian majority's aims, and does not reflect anything that can be characterised as neutral regarding the question of monoethnicity and transcending ethnic interests, which, the argument goes, refutes the claim of making a state with an identity that transcends the ethnic cleavages of the country. Although this view has been largely promoted by Serbia's foreign policy, ${ }^{96}$ one can argue that it is unlikely given the context in which Kosovo became a state ${ }^{97}$ and Kosovo's overall political and economic aims. There are at least four arguments against it. First, the process of state-building in Kosovo has been led by the idea of creating a state that rises above purely

\footnotetext{
93 See the Kosovar Institute for Policy Research and Development (n 56) on Serbian participation in Kosovo's system of government.

94 See 'Report of the International Civilian Office in Kosovo' 27 February 2009 Vienna <http://www.ico-kos.org/d/ISG\%20report\%20finalENG.pdf> accessed 5 September 2010.

95 See Serbia's Foreign Ministry Comments on 'Technical Assessment of Progress in Implementation of Standards for Kosovo' prepared by the UN GS Special Representative for Kosovo, 30 November 2007 <http://www.mfa.gov.rs/Foreinframe1.htm> accessed 20 July 2010. See also Serbia's Ministry for Kosovo and Metohija (n 13). See the opinions of Serbia's President on this in 'Address before the 64th Session of the United Nations General Assembly by Serbia's President Boris Tadić' 25 September 2009 <http://www.mfa.gov.rs/Foreinframe1.htm> accessed 20 July 2010. 'Address before the United Nations Security Council by Serbia's President Tadić' 22 January 2010 <http://www.mfa.gov.rs/Foreinframe1.htm> accessed 14 August 2010.

96 See Serbia's Ministry for Kosovo And Metohija (n 13).

97 See the proclamation of the principle of multi-ethnicity and the overall integrationist character of Kosovo's Declaration of Independence in 'Kosovo's Declaration of Independence of 17 February 2008' <http://www.assembly-kosova.org/common/docs/Dek_Pav_e.pdf> accessed 20 July 2010.
} 
ethnic interests. Besides using many power-sharing mechanisms, international state-builders have acknowledged that the state must be unified in many contexts, and state unity must transcend ethnic interests. This guarantee and the conditionality on accepting and recognising Kosovo's statehood has been reaffirmed by the acts of recognition that individual western states have given to Kosovo. Those western states that have recognised Kosovo have made it clear that it is a state that is above ethnic interests and only on such a basis has the act of recognition taken place. ${ }^{98}$ Hence, one can argue that the acts of recognition of Kosovo's statehood have affirmed that the western states recognise Kosovo only as a state that transcends ethnic interests, which rules out the prevalence of monoethnicity. ${ }^{99}$ As a result, Kosovo's leaders have comprehended that trying to create an Albanian-led polity would lead to a breach of relations with the states that have recognised Kosovo's independence, which would in turn completely diminish the international presence and image of the country. This, therefore, is an assurance that the integrationist elements in Kosovo's constitutional order have been established and will be used as such, and that Albanian-led domination cannot become a reality for this reason. ${ }^{100101102}$ Second, since the leaders of Kosovo have determined a course towards European integration, which makes them more legitimate both internationally and domestically, it is clear that the European Union would in no way accept the idea of an Albanian-led Kosovan polity. ${ }^{103}$ The

\footnotetext{
98 See the Swedish Statement of Recognition of Kosovo's Independence in 'Sweden Recognizes the Republic of Kosovo' Swedish Ministry of Foreign Affairs, press release 4 March $2008<\mathrm{http} / /$ :www.sweden.gov.se/sb/d/10358/a99714> accessed 20 July 2010. This view has generally been based on Warbirck and McGoldrick (n 25). See also the United States Statement on Recognition of Kosovo's Independence. 'Text of a Letter from the President to the President of Kosovo' White House press release, 18 February $2008<$ http//:www.kosovothankyou.com> accessed 20 July 2010.

99 Kosovo, for its part, has fully acknowledged that it has taken on the burden of implementing the Ahtisaari Settlement, which stands for a Kosovo that is above the question of Albanian and Serbian interests. See Kostovicova (n 15).

100 See the multiethnic reaction of Kosovo's Constitutional Court as regards the claim of one ethnic group that a municipal emblem does represent Albanian history (which clearly illustrates how the Constitutional Court serves the constitutional spirit of multi-ethnicity) in Kurtisi (n 86).

${ }^{101}$ As an example, see Kosovo Prime Minister Statement (n 89). See also E Pond, 'Policing Kosovo: the Challenges Awaiting EULEX' (2008) Europe's World (summer issue) <http:// www.europesworld.org/NewEnglish/Home_old/Article/tabid/191/ArticleType/articleview/ArticleID/20858/Default.aspx> accessed 16 August 2010.

${ }^{102}$ See an earlier view on the importance of domestic policy towards ethnic minorities as a means of gaining more international support for the new state in Bieber (n 14).

${ }^{103}$ See 'European Parliament resolution on the European integration process of Kosovo'. B7-0409/2010. European Parliament Document <http://www.eusrinkosovo.eu/d/ resolution\%20on\%20the\%20European\%20integration\%20process\%20of\%20Kosovo.pdf> accessed 2 August 2010; Council of the European Union, 'Council conclusions on enlargement/stabilisation and association process' 2984 ${ }^{\text {th }}$ General Affairs Council Meeting, Brussels 7 and 8 December 2009 <http://www.eusrinkosovo.eu/d/Enlargement\%20WB. pdf $>$ accessed 2 August 2010.
} 
only reality that would be acceptable for the European Union is a Kosovo with integrationist elements which promotes an identity that rises above the ethnic divisions of the polity. Hence, it can be argued that there is no way for domestic political leaders to avoid this fact, thus proving that the integrationist elements within Kosovo's constitutional system must be used as such, and no Albanianisation is possible. ${ }^{104}$ Third, there is no external factor, such as the state of Albania could have been, to support the idea of the Albanianisation of Kosovo's polity as opposed to a polity that is integrationist in nature. It should be noted that Albania itself needs to recognise and to support the current ethnically-neutral constitutional regime in Kosovo in order to be considered a potential candidate for EU membership. ${ }^{105}$ Therefore, since there is no external influence to promote this idea, particularly no influence from Albania (which one might suppose to have such an interest), one can argue that the integrationist elements in Kosovo's constitutional regime are likely to remain. Fourth, there is convincing evidence, which has been internationally acknowledged that, most importantly, Kosovo's political leaders and Kosovan Albanian political leaders have demonstrated that they want a state that is above ethnic interests, with an identity that neither supports nor discriminates against any ethnic group. Though this will need time to be strengthened, there is a tendency at least to move in this direction. Hence, one can argue that the integrationist elements in Kosovo's constitutional regime exist, or are being empowered, and that there is no way that the idea of Kosovo being for Albanians only can exist in domestic and international reality. ${ }^{106}$

Thus, one can argue that Kosovo's constitutional regime has both consociational and integrationist elements, and there is no evidence to argue against their presence. Consequently, it can be argued that the international state-builders of Kosovo have produced a constitutional regime that offers a harmony between the two. Such harmony between consociational and integrationist elements has been constructed primarily to allow the Serbian minority to participate in the power-sharing system

\footnotetext{
104 See Pond (n 101).

${ }^{105}$ See F Korenica and D Doli, 'Europe and the Albanian Parliamentary Election of June 2009' (2010) 56 European Parties, Elections and Referendums Network, Sussex European Institute <http://www.sussex.ac.uk/sei/documents/epernalbania2009.pdf> accessed 2 October 2010.

${ }^{106}$ See Kosovo Prime Minister Statement (n 89); Pond (n 101); 'Improving Inter-Ethnic Relations in Kosovo' Kosovo Prime Minister Statement, Addressing the Project on Interethnic Relations, 22 April 2009 Prishtina <http://www.kryeministri-ks.net/?page=2,104,535> accessed 2 August 2010; Kosovo Prime Minister Statement Addressing the International Steering Group on Kosovo 14 July 2010 Vienna <http://www.kryeministri-ks. net/?page $=2,104,156>1$ accessed 2 August 2010; Kosovar Institute for Policy Research and Development (n 56).
} 
on the one hand, while allowing the central elements of state rule to be built on an integrationist basis on the other. This has produced Kosovo's polity, which is both accommodationist in terms of Serbian participation in power-sharing institutions and integrationist in the parts of the polity which sustain the effectiveness of Kosovo as a state. ${ }^{107}$ This model, though placed in the middle of consociation and integration, offers a polity that is much more functional and sustainable than Bosnia and Herzegovina, while at the same time the Serbian minority and other minorities enjoy a rather distinguished and privileged position in society. As a result, the removing of the ethnic cleavage in Kosovo through a system of power-sharing has not endangered the strength of Kosovo's polity.

\section{Conclusion}

This article has discussed the problem of societal cleavage in Kosovo and examined the constitutional system that has been created to facilitate and promote the softening of the relationship between the groups concerned.

The article started by briefly describing the theoretical background to the issue of societal cleavages and the mechanisms to remove them. The article then went on to explain the origins of the societal cleavages in Kosovo and illustrated the most serious attempts to exacerbate the problem. Following this, the article illustrated the international endeavours to build the state of Kosovo, and the main concerns in this process.

The article went on to discuss the constitutional regime of Kosovo in the light of the accommodationist-integrationist debate. In its analysis, the article examined the main elements of the accommodationist school of thought in Kosovo's constitutional regime, namely the grand coalition, proportionality, veto rights and cultural autonomy. By looking at each segment of consociationalism in Kosovo's constitutional regime, the article also observed integrationist elements. The article also offered a number of arguments that illustrated that, although Kosovo's constitutional regime is thought of as consociational, it has a number of very stable integrationist elements, thus proving that the constitutional regime of Kosovo has both consociational and integrationist elements.

The article argues that the constitutional regime of Kosovo has been constructed to offer power-sharing governance to ethnic communities in almost every component of the polity. However, the most significant components of the latter have an integrationist nature. Therefore, the article

107 For a similar, though general view, see Marko (n 9). 
concludes that the international state-builders of Kosovo have sought to reach a constitutional regime for Kosovo that offers power-sharing, political unity and institutional sustainability at the same time. Hence, the harmony between the consociational and integrationist elements in Kosovo's constitutional regime is clear. In conclusion, Kosovo's constitutional regime is a successful one, since it addresses the issue of providing shared powers to ethnic communities, while ensuring that the state functions in a sustainable and feasible political reality. 